Archive for

Organic Chemistry

Arkivoc 2019, part vi, 190-199

\title{
An expeditious one-pot multicomponent synthesis of sterically hindered bis-1,2,4-triazolopyridazines under solvent-free conditions
}

\author{
Ranjana Aggarwal, ${ }^{a} *$ Mamta, $^{a}$ and Garima Sumran ${ }^{b}$ \\ ${ }^{a}$ Department of Chemistry, Kurukshetra University, Kurukshetra, 136119, India \\ ${ }^{b}$ Department of Chemistry, D. A. V. College (Lahore), Ambala City 134 003, Haryana, India \\ Email: ranjanaaggarwal67@gmail.com
}

Received 06-26-2019

Accepted 10-18-2019

Published on line 11-18-2019

\section{Abstract}

A simple and ecologically facile synthesis of sterically hindered 3,6-disubstituted-bis-1,2,4-triazolo-[4,3-b:3',4'f]pyridazines was accomplished via a three-component reaction sequence between 3,6-dihydrazinopyridazine, an aromatic or heteroaromatic aldehyde and iodobenzene diacetate (IBD) on grinding at room temperature. The 3,6-bis-arylidenehydrazinopyridazine intermediates, generated in situ, undergo oxidative cyclization to afford the title compounds. The present protocol has excellent yields, short reaction times, broad substrate scope, is a solvent-free greener synthesis, and has an easy purification of product.

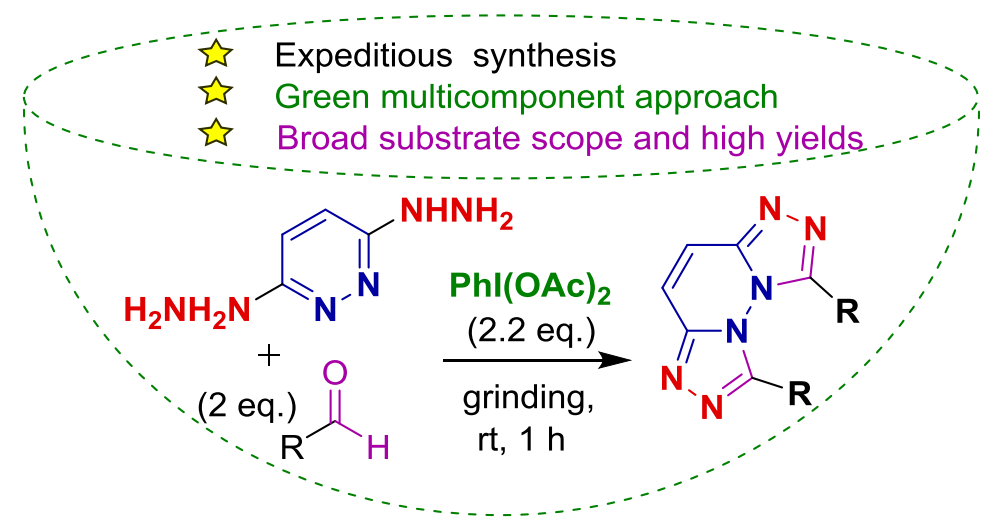

Keywords: 3,6-Dihydrazinopyridazine, 3,6-bis-arylidenehydrazinopyridazine, 3,6-di-substituted-bis-1,2,4triazolo-[4,3-b:3',4'-f]pyridazines, iodobenzene diacetate, multicomponent synthesis, one-pot 


\section{Introduction}

The efficiency of a chemical synthesis can be measured not only by its selectivity, scalability and overall yield but also by its feedstock, time consumption and energy requirements, as well as the toxicity and hazards of the chemicals and the pathway involved. Multicomponent reactions (MCRs) have emerged as prominent strategies for the efficient synthesis of various high merit chemical entities including natural products, pharmaceuticals and poly-heterocyclic compounds which not only have molecular diversity but also architectural complexity. ${ }^{1-3}$ Additionally, they involve several transformations in a single manipulation. Many MCRs are superior to conventional methods owing to their enhanced selectivity, high atom-efficiency, cleaner reaction profiles, minimum by-product formation, ease of manipulation, cost effectiveness and relatively benign conditions.

Recently, a solvent-free strategy delineates further extremely powerful green chemical protocols from both the economic and convenience perspective in terms of execution of complex reactions within limited time with significant energy saving, avoidance of intermediates isolation, separation of side products at each step and higher yields in target synthesis.

The chemistry of pyridazine and its derivatives has sustained considerable interest owing to the presence of two nitrogen atoms that present coordination sites to a variety of metal ions and their property of forming and strengthening assembly of supramolecular and polymeric architectures. ${ }^{4}$ Other technological applications involve the development of new $\pi$-conjugated organic materials for liquid crystals, electronic and optoelectronic devices. ${ }^{5,6}$ The pyridazine ring appears in natural products such as antifungal antibiotic pyridazomycin and meroterpenoid azamerone. ${ }^{7}$ The pyridazine scaffold as a privileged structure is present in a large number of pharmacologically active drugs such as talazoparib (poly ADP ribose polymerase (PARP) inhibitor with potential antineoplastic activity), minaprine (antidepressant), cilazapril (antihypertensive), irdabisant (histamine $\mathrm{H}_{3}$ receptor antagonist), pipofezine (antidepressant), emorphazone (anti-inflammatory) and LDN-212320 (excitatory amino acid transporter 2 (EAAT2) activator) (Figure 1) $\cdot^{7-9}$ In addition, pyridazines appear in plant growth regulators and crop protection agents such as chloridazon, norflurazon, pyridate and pyridaben. ${ }^{10}$ Pyridazine-fused derivatives comprise a class of biologically active heterocyclic compounds having potential in the field of drug design and development. Among fused pyridazine-containing heterocycles, pyrrolo[1,2-b]pyridazines and imidazo[1,2-b]pyridazines exhibit anticancer ${ }^{11}$ and monopolar spindle 1 (Mps1) inhibitory activities, respectively. ${ }^{12}$ Literature precedents indicate that 1,2,4-triazolo[4,3-b]pyridazine derivatives, in particular, exhibit extensive pharmacological activities which encompass anticonvulsant, ${ }^{13}$ herbicidal, ${ }^{14}$ antitubulin, ${ }^{15}$ antimicrobial, ${ }^{16}$ anxiolytic activity, ${ }^{17}$ as well as tankyrase ${ }^{18}$ and panphosphodiesterase (PDE) inhibitors. ${ }^{19}$ (S)-6-(1-(6-(1-Methyl-1H-pyrazol-4-yl)-[1,2,4]triazolo[4,3-b]pyridazin-3$\mathrm{yl}$ )ethyl)quinoline (PF-04254644) was identified as a potent and exquisitely selective c-Met inhibitor but development was terminated due to cardiotoxicity (Figure 1). ${ }^{9}$ SAR125844 is reported as a potent and selective MET kinase inhibitor in MET-amplified and MET pathway-addicted tumors. ${ }^{20}$ Very recently our group explored in vitro antiproliferative activity of a series of 6-chloro-3-substituted-[1,2,4]triazolo[4,3-b]pyridazines against three human cancer cell lines namely SB-ALL, NALM-6 and MCF-7 using the MTT assay and the most active compounds induced apoptosis in Nalm- 6 cells via caspase $3 / 7$ activation. ${ }^{21}$ 
<smiles>Cn1ncnc1[C@H]1c2n[nH]c(=O)c3cc(F)cc(c23)N[C@H]1c1ccc(F)cc1</smiles>

Talazoparib

(PARP inhibitor)

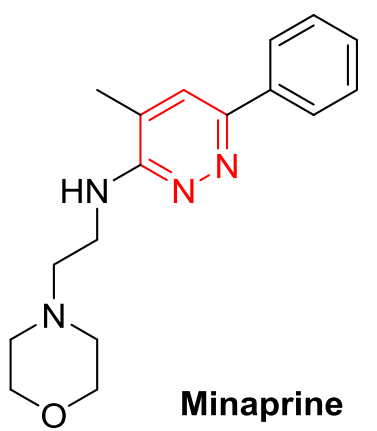

(Antidepressant)

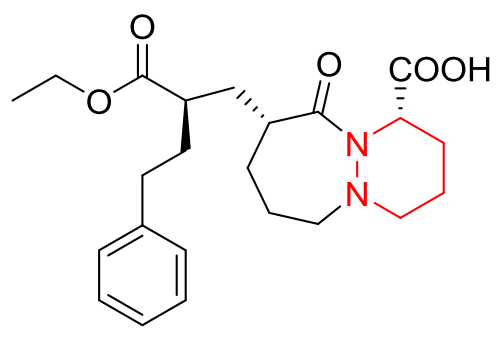

Cilazapril

(Antihypertensive)

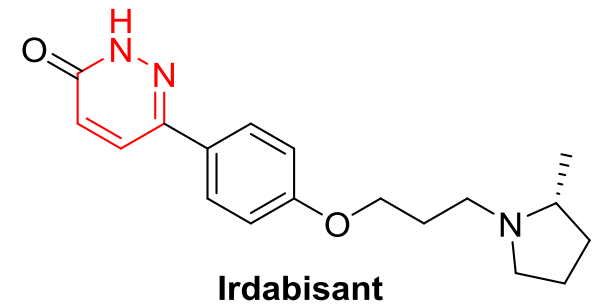

(Histamine $\mathrm{H}_{3}$ receptor antagonist)<smiles>CN1CCN(c2cc3c(nn2)Oc2ccccc2N3C)CC1</smiles>

Pipofezine

(Antidepressant)<smiles>CCOc1c(N2CCOCC2)cnn(C)c1=O</smiles>

Emorphazone

(Anti-inflammatory)<smiles>[R]Nc1cnn(-c2cccc([R])c2)c(=O)c1Cl</smiles>

Chloridazon, $\mathrm{R}, \mathrm{R}_{1}=\mathrm{H}$ Norflurazon, $\mathrm{R}=\mathrm{CF}_{3} ; \mathrm{R}_{1}=\mathrm{CH}_{3}$ (Herbicide)<smiles>Cc1ccccc1CSc1ccc(-c2ccccn2)nn1</smiles>

LDN-212320

(EAAT2 activator and neuroprotective)<smiles>C[C@@H](c1ccc2ncccc2c1)c1nnc2ccc(-c3cnn(C)c3)nn12</smiles>

PF-04254644

(c-Met inhibitor)

Figure 1. Structures of some clinical candidates and biologically active molecules containing a pyridazine ring.

Synthesis of bis-1,2,4-triazolo[4,3-b:3',4'-f]pyridazines has been achieved by only two general methods. The first consists in the construction of the second triazole ring by cyclization of 6-arylidenehydrazino-3-aryl1,2,4-triazolo[4,3-b]pyridazine to bis-1,2,4-triazolo[4,3-b:3',4'-f]pyridazine on treatment with an oxidant such as $\mathrm{Br}_{2} / \mathrm{AcOH}$ or lead tetracetate, ${ }^{22}$ or $\mathrm{Me}_{4} \mathrm{NBr} /$ oxone ${ }^{\oplus 3}$ Whereas, formation of 6-arylidenehydrazino-3-aryl1,2,4-triazolo[4,3-b]pyridazine involves three steps: i) conversion of 3,6-dichloropyridazine into 6-chloro-3hydrazinopyridazine, ii) condensation with an aldehyde, iii) oxidative cyclization of the resulting hydrazone to triazole. The second method comprises simultaneous formation of both triazole rings by oxidative cyclization of 3,6-bis-(arylidenehydrazino)pyridazines using $\mathrm{Br}_{2} / \mathrm{AcOH}$ or lead tetraacetate ${ }^{16}$ and by the reaction of 3,6dichloropyridazine with two equivalents of acid hydrazides. ${ }^{24}$ However, these methods suffer from several limitations such as harsh reaction conditions, multistep synthesis, use of toxic reagents, high reaction temperature, tedious work-up, extended reaction times and unsatisfactory yields.

In order to overcome these limitations, we have recently reported iodobenzene diacetate (IBD) mediated stepwise synthesis of 3,6-disubstituted-bis-1,2,4-triazolo[4,3-b:3',4'-f]pyridazines in dichloromethane as solvent via oxidative intramolecular cyclization of 6-arylidenehydrazino-3-aryl-1,2,4-triazolo[4,3b]pyridazines. ${ }^{25}$ Four synthesized compounds were evaluated for their in vitro cytotoxic activity against the 
human cervical carcinoma (HeLa) cell line using MTT assay, displaying low activity. X-ray crystallographic studies of sterically strained 3,6-di-(2'-fluorophenyl)-bis-1,2,4-triazolo[4,3-b:3',4'-f]pyridazine I and 3,6-di-(4'fluorophenyl)-bis-1,2,4-triazolo[4,3-b:3',4'-f]pyridazine II revealed that the pyridazine ring has a twisted conformation leading to nonplanar tricyclic core (Scheme 1). Thus, more efficient, economically viable and expeditious methods for synthesis of the title compounds are of significant interest.

(a)
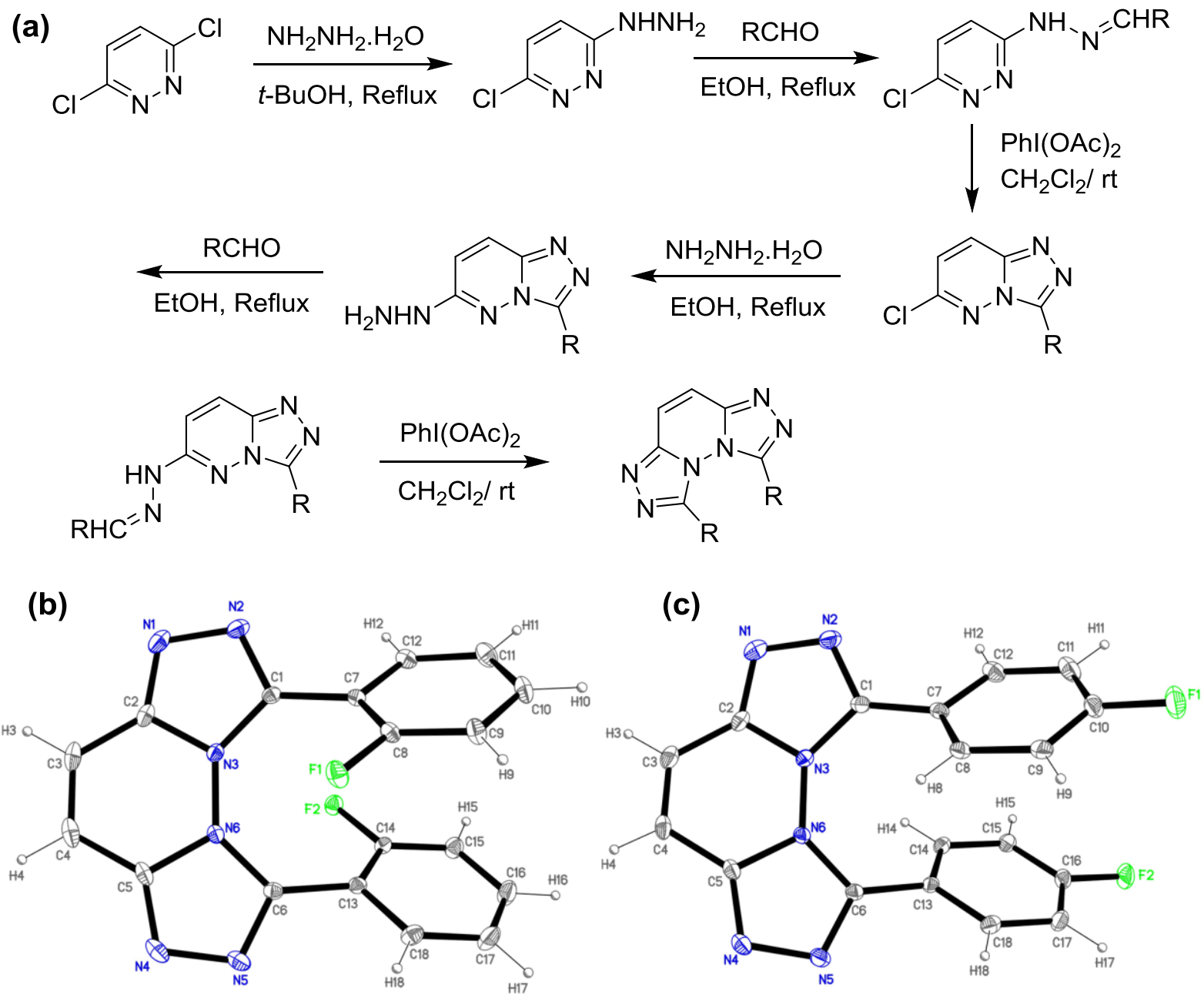

Scheme 1. (a) Recently reported synthesis of 3,6-disubstituted-bis-1,2,4-triazolo[4,3-b:3',4'-f]pyridazines. ${ }^{21,25}$ ORTEP plots of (b) I and (c) II with ellipsoids at $20 \%$ probability.

In view of these observations and as a part of our program on hypervalent iodine reagents in organic transformations ${ }^{26-30}$ and in continuance of our ongoing interest to develop solvent-free synthesis of heterocyclic compounds, ${ }^{31,32}$ it was envisaged in the present study to synthesize 3,6-disubstituted-bis-1,2,4triazolo[4,3-b:3',4'-f]pyridazines through an efficient, concise and ecofriendly multicomponent solvent-free protocol.

\section{Results and Discussion}

In an endeavour to synthesize the title compounds, a mixture of 3,6-dihydrazinopyridazine 1 and two equivalents of benzaldehyde (2a) was ground in a pestle and mortar at room temperature. The reaction was 
regularly monitored at short intervals by TLC which indicated completion of reaction in 20 minutes by consumption of reactants and appearnce of a new spot. Work-up afforded a solid product corresponding to 3,6-bis-benzylidenehydrazinopyridazine (3a) which was confirmed by comparing its melting point with the literature value. ${ }^{22}$ Subsequently $3 \mathbf{3}$ on grinding with 2.2 equivalents of IBD for one hour underwent oxidative cyclization to afford 3,6-diphenyl-bis-1,2,4-triazolo[4,3-b:3',4'-f]pyridazine 4 a in $85 \%$ yield. Formation of $4 a$ was confirmed on the basis of co-TLC and mixed $\mathrm{mp}$ with a sample prepared via the sequential route. ${ }^{25}$ With optimized reaction conditions in hand, reaction of 1 with benzaldehyde (2a) was repeated under same condition but without isolation of 3a. Compound 3a generated in situ undergoes oxidative cyclization upon addition of 2.2 equivalents of IBD under grinding for another one hour to give 4 a (Scheme 2).

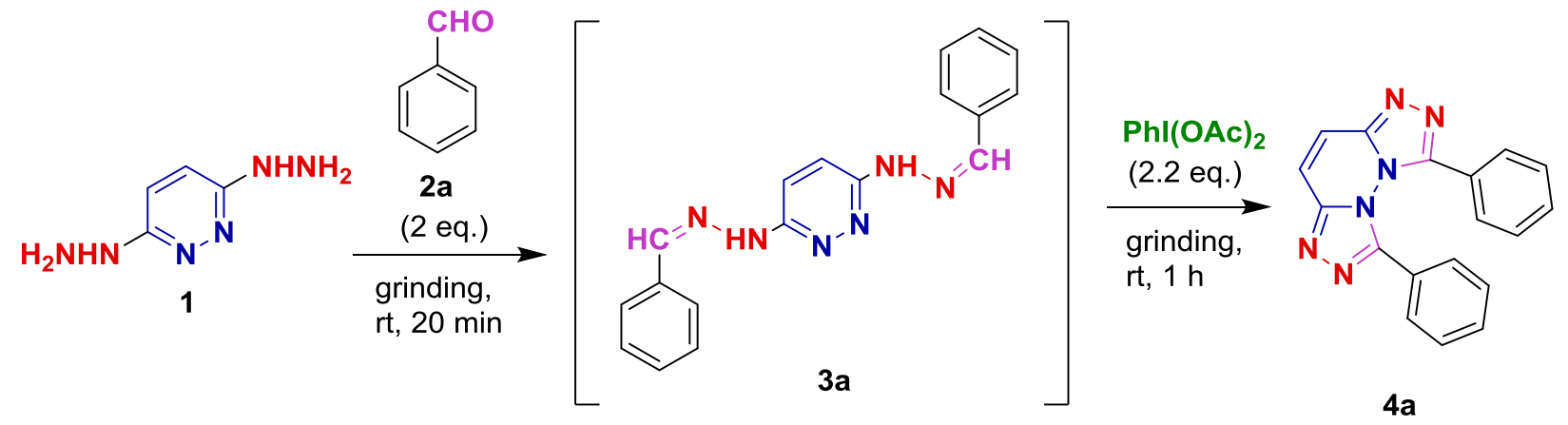

Scheme 2. Multicomponent one-pot solvent-free synthesis of 3,6-diphenyl-bis-1,2,4-triazolo[4,3-b:3',4'f]pyridazine (4a).

Encouraged by this success, and to examine the substrate scope of the method, a series of bis-1,2,4triazolo[4,3-b:3',4'-f]pyridazine derivatives $\mathbf{4 b - I}$ were envisaged having mono, di-substituted aryl and heteroaryl ring at positions 3 and 6 of the triazole ring. We explored the substrate scope by grinding various aldehydes (2b-I) with 3,6-dihydrazinopyridazine 1 followed by addition of IBD, which provided 3,6di(aryl/heteroaryl)-bis-1,2,4-triazolo[4,3-b:3',4'-f]pyridazines 4b-I in uniformly high yields in just one hour and twenty mintues following a simple work-up (Scheme 3). A series of mono and di-substituted benzaldehydes bearing electron-donating groups $\left(\mathrm{CH}_{3}, \mathrm{OCH}_{3}\right)$ as well as electron-withdrawing groups $(\mathrm{F}, \mathrm{Cl}, \mathrm{Br})$ at ortho-, meta- or para-positions and heteroaryl aldehydes (furfuraldehyde and thiophene-2-carbaldehyde) reacted efficiently to give desired products. The results presented in Scheme 3 clearly indicate that the new one-pot multicomponent synthesis affords improved overall yields (54-68\%) for the title compounds, as compared to the reported procedure (20-29\%) that involves five steps starting from 6-chloro-3-hydrazinopyridazine (Scheme 1). ${ }^{21,25}$ The same conversion took longer times for completion when carried out by conventional stepwise method. ${ }^{21,25}$ Compound 3a was isolated only in the case of benzaldehyde. Other hydrazones were not isolated. All the synthesized compounds 4 were identified on the basis of their $\mathrm{mp}$, mixed $\mathrm{mp}$ and co-TLC with same samples synthesized by the conventional method. ${ }^{25}$ 


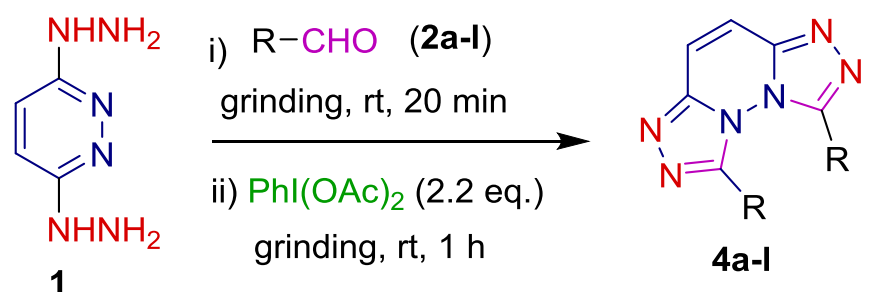<smiles>c1ccc(-c2nnc3ccc4nnc(-c5ccccc5)n4n23)cc1</smiles>

$4 a$ $68 \%$ [27\%]<smiles>Brc1ccc(-c2nnc3ccc4nnc(-c5ccc(Br)cc5)n4n23)cc1</smiles>

$4 e$ $61 \%[23 \%]$<smiles>COc1ccc(OC)c(-c2nnc3ccc4nnc(-c5cc(OC)ccc5OC)n4n23)c1</smiles>

4i<smiles>Clc1ccccc1-c1nnc2ccc3nnc(-c4ccccc4Cl)n3n12</smiles>

4b<smiles>Clc1ccc(-c2nnc3ccc4nnc(-c5ccc(Cl)cc5)n4n23)cc1</smiles>

4c<smiles>Brc1cccc(-c2nnc3ccc4nnc(-c5cccc(Br)c5)n4n23)c1</smiles>

$59 \%$ [20\%] $59 \%[23 \%]$ $58 \%$ [21\%]<smiles>COc1ccc(-c2nnc3ccc4nnc(-c5ccc(OC)cc5)n4n23)cc1</smiles>

$4 f$

$55 \%$ [26\%]<smiles>COc1ccc(-c2nnc3ccc4nnc(-c5ccc(OC)c(OC)c5)n4n23)cc1OC</smiles>

$4 j$<smiles>Fc1ccc(-c2nnc3ccc4nnc(-c5ccc(F)cc5)n4n23)cc1</smiles>

$59 \%$ [29\%]

$58 \%$ [24\%]<smiles>c1csc(-c2nnc3ccc4nnc(-c5cccs5)n4n23)c1</smiles>

4k

$58 \%[23 \%]$<smiles>c1coc(-c2nnc3ccc4nnc(-c5ccco5)n4n23)c1</smiles>

4I

$54 \%[21 \%]$

Scheme 3. Substrate scope and isolated yields of bis-1,2,4-triazolo[4,3-b:3',4'-f]pyridazines (4a-I) obtained from 3,6-dihydrazinopyridazine 1. Yields in parenthesis correspond to isolated yield for product 4 obtained from the sequential procedure starting from 6-chloro-3-hydrazinopyridazine. ${ }^{21,25}$ 


\section{Conclusions}

Summarising, we have demonstrated an efficient, economical, and versatile protocol to synthesize valuable bis-triazolo[4,3- $\left.b: 3^{\prime}, 4^{\prime}-f\right]$ pyridazines 4 via one-pot solvent-free multicomponent syntheses using IBD as environmentally benign non-metallic oxidant. The superiority of the MCR route over the conventional approach is due to its two-step sequential synthesis, atom-economy, short reaction times, improved yields, no isolation of intermediates and operational simplicity. Whereas conventional synthesis of target compounds 4 , starting from 6-chloro-3-hydrazinopyridazine as presursor, involves a five-step sequence, long reaction times, low overall yields due to multisteps, isolation and purification of intermediates at each steps and high energy consumption. Moreover, conventional synthesis using lead tetraacetate as oxidant is ecologically unfriendly.

\section{Experimental Section}

General. Melting points were determined in digital melting point apparatus MEPA and are uncorrected. Analytical thin layer chromatography (TLC) was performed using Merck Kieselgel 60 F254 silica gel plates. Visualisation was performed under UV light using Ultra Violet Fluorescence Inspection Cabinet (Perfit, India). 3,6-Dihydrazinopyridazine (1) was prepared from 3,6-dichloropyridazine according to the literature procedure. $^{33}$

3,6-bis-Benzylidenehydrazinopyridazine (3a). A mixture of 3,6-dihydrazinopyridazine (1) (280 mg, $2.0 \mathrm{mmol})$ and 2 equivalents of benzaldehyde $(2 \mathrm{a})(424 \mathrm{mg}, 4.0 \mathrm{mmol})$ was ground in a porcelain pestle and mortar. The TLC of the reaction mixture evinced the completion of reaction in $20 \mathrm{~min}$ as there were no spots corresponding to the reactants on TLC. On completion of reaction, EtOH ( $3 \mathrm{~mL}$ ) was added to the reaction mixture. A solid separated out which was filtered off and recrystallized from EtOH. Yield $75 \%$; $\mathrm{mp} 260.5^{\circ} \mathrm{C}$; Lit $\mathrm{mp} 261-262^{\circ} \mathrm{C}^{22}$

3,6-Diphenyl-bis-1,2,4-triazolo[4,3-b:3',4'-f]pyridazine (4a). A mixture of 3,6-bis-benzylidenehydrazinopyridazine (3a) (316 mg, $1.0 \mathrm{mmol}$ ) and 2.2 equivalents of IBD (708 $\mathrm{mg}, 2.2 \mathrm{mmol}$ ) was ground in a pocelain pestle and mortar at rt. TLC of the reaction mixture was executed at regular intervals which evinced the completion of reaction in $1 \mathrm{~h}$. The crude product was triturated with petroleum ether ether in order to remove iodobenzene and then the residue recrystallized using $\mathrm{EtOH}$ to afford $4 \mathrm{a}$ as single product. The product was characterized on the basis of its $\mathrm{mp}$, mixed $\mathrm{mp}$ and co-TLC with a sample synthesized through the conventional route. Yield $85 \%$; $\mathrm{mp} 274{ }^{\circ} \mathrm{C}$; Lit $\mathrm{mp} 277-278^{\circ} \mathrm{C} .{ }^{22,25}$

General procedure for one-pot synthesis of 3,6-disubstituted-bis-1,2,4-triazolo[4,3-b:3',4'-f]pyridazines (4aI). A mixture of 3,6-dihydrazinopyridazine (1) $(280 \mathrm{mg}, 2.0 \mathrm{mmol})$ and 2 equivalents of the appropriate aldehyde (2) $(4.0 \mathrm{mmol})$ was ground in a pestle and mortar for 20 min which resulted in the formation of corresponding 3,6-bis-arylidenehydrazinopyridazine (3). After complete consumption of aldehyde, 2.2 equivalents of IBD $(2.2 \mathrm{mmol})$ was added and the reaction mixture was ground for another $1 \mathrm{~h}$. TLC of the reaction mixture was overseen at regular intervals. Solid separated out after triturating with petroleum ether was filtered off and recrystallized with EtOH to afford the corresponding bis-1,2,4-triazolo[4,3-b][3',4'f]pyridazine (4a-I).

Compounds $4 \mathrm{a}-\mathrm{I}$ were identified on the basis of their $\mathrm{mp}$, mixed $\mathrm{mp}$ and co-TLC with conventionally synthesized $4 a-1 .{ }^{25}$ NMR spectra of known compounds are reported. ${ }^{25}$ 
3,6-Diphenyl-bis-1,2,4-triazolo-[4,3-b:3',4'-f]pyridazine (4a). mp $274{ }^{\circ} \mathrm{C}$; Lit mp $274{ }^{\circ} \mathrm{C} .{ }^{25}$

3,6-Di-(2-chlorophenyl)-bis-1,2,4-triazolo-[4,3-b:3',4'-f]pyridazine (4b). mp $201.5{ }^{\circ} \mathrm{C}$; Lit mp $201.5^{\circ} \mathrm{C} .{ }^{25}$ 3,6-Di-(4-chlorophenyl)-bis-1,2,4-triazolo-[4,3-b:3',4'-f]pyridazine (4c). mp $244^{\circ} \mathrm{C}$; Lit mp $244.5^{\circ} \mathrm{C} .{ }^{25}$ 3,6-Di-(3-bromophenyl)-bis-1,2,4-triazolo-[4,3-b:3',4'-f]pyridazine (4d). mp $190{ }^{\circ} \mathrm{C}$; Lit mp $190^{\circ} \mathrm{C} .{ }^{25}$ 3,6-Di-(4-bromophenyl)-bis-1,2,4-triazolo-[4,3-b:3',4'-f]pyridazine (4e). mp $197^{\circ} \mathrm{C}$; Lit mp $197^{\circ} \mathrm{C} .{ }^{25}$ 3,6-Di-(2-fluorophenyl)-bis-1,2,4-triazolo-[4,3-b:3',4'-f]pyridazine (4f). mp $257.5^{\circ} \mathrm{C}$; Lit mp $257.5^{\circ} \mathrm{C}$. ${ }^{25}$ 3,6-Di-(4-fluorophenyl)-bis-1,2,4-triazolo-[4,3-b:3',4'-f]pyridazine (4g). mp $292.5^{\circ} \mathrm{C}$; Lit mp $292.5^{\circ} \mathrm{C} .{ }^{25}$ 3,6-Di-(4-methoxyphenyl)-bis-1,2,4-triazolo-[4,3-b:3',4'-f]pyridazine (4h). mp $224^{\circ} \mathrm{C}$; Lit mp $225^{\circ} \mathrm{C} .{ }^{25}$ 3,6-Di-(2,5-dimethoxyphenyl)-bis-1,2,4-triazolo-[4,3-b:3',4'-f]pyridazine (4i). mp >315 ${ }^{\circ} \mathrm{C}$; Lit $\mathrm{mp}>315^{\circ} \mathrm{C}$. ${ }^{25}$ 3,6-Di-(3,4-dimethoxyphenyl)-bis-1,2,4-triazolo-[4,3-b:3',4'-f]pyridazine (4j). mp $226^{\circ} \mathrm{C}$; Lit mp $226^{\circ} \mathrm{C} .{ }^{25}$ 3,6-Di-(thien-2-yl)-bis-1,2,4-triazolo-[4,3-b:3',4'-f]pyridazine (4k). mp $232{ }^{\circ} \mathrm{C}$; Lit mp $231^{\circ} \mathrm{C} .{ }^{25}$ 3,6-Di-(furan-2-yl)-bis-1,2,4-triazolo-[4,3-b:3',4'-f]pyridazine (4I). mp $225^{\circ} \mathrm{C}$; Lit mp $225^{\circ} \mathrm{C}^{25}$

\section{Acknowledgements}

We are grateful to the Haryana State Council for Science and Technology (HSCST), Haryana for providing financial assistance to Mamta.

\section{References}

1. Ibarra, I. A.; Islas-Jácome, A.; González-Zamora, E. Org. Biomol. Chem. 2018, 16, 1402-1418. https://doi.org/10.1039/c7ob02305g

2. Boukis, A. C.; Reiter, K.; Frölich, M.; Hofheinz, D.; Meier, M. A. R. Nat. Commun. 2018, 9, 1439. https://doi.org/10.1038/s41467-018-03784-x

3. van der Heijden, G.; Ruijter, E.; Orru, R. V. A. Synlett 2013, 666-685. https://doi.org/10.1055/s-0032-1318222

4. Domasevitch, K. V.; Solntsev, P. V.; Krautscheid, H.; Zhylenko, I. S.; Rusanov, E. B.; Chernega, A. N. Chem Commun. 2012, 48, 5847-5849.

https://doi.org/10.1039/C2CC31770B

5. Achelle, S.; Ple', N. Turck, A. RSC Adv. 2011, 1, 364-388.

https://doi.org/10.1039/C1RA00207D

6. Park, Y. S.; Kim, D.; Lee, H.; Moon, B. Org. Lett. 2006, 8, 4699-4702. https://doi.org/10.1021/ol061711q

7. Wermuth, C. G. Med. Chem. Commun. 2011, 2, 935-941. https://doi.org/10.1039/c1md00074h

8. Chelini, A.; Brogi, S.; Paolino, M.; Capua, A. D.; Cappelli, A.; Giorgi, G.; Farzad, M.; Mannelli, L. D. C.; Micheli, L.; Ghelardini, C.; Anzini, M. J. Med. Chem. 2017, 60, 5216-5221.

https://doi.org/10.1021/acs.jmedchem.7b00383

9. Cui, J. J.; Shen, H.; Tran-Dube, M.; Nambu, M.; Mc-Tigue, M.; Grodsky, N.; Ryan, K.; Yamazaki, S. ; Aguirre, S.; Parker, M.; Li, Q.; Zou, H.; Christensen, J. J. Med. Chem. 2013, 56, 6651-6665. https://doi.org/10.1021/im400926x 
10. Lamberth, C. J. Heterocycl. Chem. 2017, 54, 2974-2984. https://doi.org/10.1002/jhet.2945

11. Popovici, L.; Amarandi, R. M.; Mangalagiu, I. I.; Mangalagiu, V.; Danac, R. J. Enzyme Inhib. Med. Chem. 2019, 34, 230-243. https://doi.org/10.1080/14756366.2018.1550085

12. Kusakabe, K.; Ide, N.; Daigo, Y.; Itoh, T.; Yamamoto, T.; Hashizume, H.; Nozu, K.; Yoshida, H.; Tadano, G.; Tagashira, S.; Higashino, K.; Okano, Y.; Sato, Y.; Inoue, M.; Iguchi, M.; Kanazawa, T.; Ishioka, Y.; Dohi, K.; Kido, Y.; Sakamoto, S.; Ando, S.; Maeda, M.; Higaki, M.; Baba, Y.; Nakamura, Y. J. Med. Chem. 2015, 58, 1760-1775. https://doi.org/10.1021/jm501599u

13. Guan, Li. P.; Sui, X.; Deng, X. Q.; Quan, Y. C.; Quan, Z. S. Eur. J. Med. Chem. 2010, 45, 1746-1752. https://doi.org/10.1016/i.ejmech.2009.12.077

14. Zhu, Y. Q.; Hu, X. H.; Xu, H.; Wang, Y.; Zou, X. M.; Yang, H.Z. Arkivoc. 2008, (12), 30-41. https://doi.org/10.3998/ark.5550190.0009.c04

15. Xu, Q.; Wang, Y.; Xu, J.; Sun, M.; Tian, H.; Zuo, D.; Guan, Q.; Bao, K.; Wu, Y.; Zhang, W. Med. Chem. Lett. 2016, 7, 1202-1206. https://doi.org/10.1021/acsmedchemlett.6b00252

16. Ruso, J. S.; Nagappan, R.; Kumaran, R. S.; Srinivas, C.; Murthy, K. N.; Soumya, K. J. Kor. Chem. Soc. 2014, 58, 377-380.

https://doi.org/10.5012/jkcs.2014.58.4.377

17. Albright, J. D.; Moran, D. B.; Wright Jr., W. B.; Collins, J. B.; Beer, B.; Lippa, A. S.; Greenblatt, E. N. J. Med. Chem. 1981, 24, 592-600.

https://doi.org/10.1021/im00137a020

18. Liscio, P.; Carotti, A.; Asciutti, S.; Karlberg, T.; Bellocchi, D.; Llacuna, L.; Macchiarulo, A.; Aaronson, S. A.; Schüler, H.; Pellicciari, R.; Camaioni, E. J. Med. Chem. 2014, 57, 2807-2812.

https://doi.org/10.1021/jm401356t

19. Skoumbourdis, A. P.; LeClair, C. A.; Stefan, E.; Turjanski, A. G.; Maguire, W.; Titus, S. A.; Huang, R.; Auld, D. S.; Inglese, J.; Austin, C. P.; Michnick, S. W.; Menghang Xia, M.; Thomas, C. J. Bioorg. Med. Chem. Lett. 2009, 19, 3686-3692.

https://doi.org/10.1016/j.bmcl.2009.01.057

20. Egile, C.; Kenigsberg, M.; Delaisi, C.; Begassat, F.; Do-Vale, V.; Mestadier, J.; Bonche, F.; Benard, T.; Nicolas, J. P.; Valence, S.; Lefrance, C.; Francesconi, E.; Castell, C.; Lefebvre, A. M.; Nemecek, C.; Calvet, L.; Goulaouic, H. Mol. Cancer Ther. 2015, 14, 384-394.

https://doi.org/10.1158/1535-7163

21. Mamta, Aggarwal, R.; Sadana, R.; Ilag, J.; Sumran, G. Bioorg. Chem. 2019, 86, 288-295. https://doi.org/10.1016/i.bioorg.2019.01.049

22. Pollak, A.; Tišler, M. Tetrahedron 1966, 22, 2073-2079. https://doi.org/10.1016/S0040-4020(01)82127-X

23. Ruso, J. S.; Nagappan, R.; Kumaran, R. S. J. Kor. Chem. Soc. 2013, 57, 606-611. https://doi.org/10.5012/jkcs.2013.57.5.606

24. El-Salam, N. M. A.; Shoaibi, Z. Y. A.; Ahmed, G. A. E-Journal Chem. 2011, 8, 1944-1950. https://doi.org/10.1155/2011/612825

25. Aggarwal, R.; Mamta, Sumran, G.; Torralba, M. C. J. Mol. Str. 2019, 1185, 379-391. https://doi.org/10.1016/i.molstruc.2019.02.082 
26. Aggarwal, R.; Sumran, G. Indian J. Chem. 2006, 45B, 2690-2695. http://nopr.niscair.res.in/handle/123456789/6776

27. Aggarwal, R.; Rani, C.; Sumran, G. Synth. Commun. 2014, 44, 923-928. https://doi.org/10.1080/00397911.2013.832775

28. Sumran, G.; Aggarwal, R. J. Sulfur Chem. 2015, 36, 170-177. https://doi.org/10.1080/17415993.2014.996221

29. Sumran, G.; Aggarwal, R.; Hooda, M.; Sanz, D.; Claramunt, R. M. Synth. Commun. 2018, 48, 439-446. https://doi.org/10.1080/00397911.2017.1407791

30. Sumran, G.; Aggarwal, R.; Mittal, A.; Aggarwal, A.; Gupta, A. Bioorg. Chem. 2019, 88, 102932. https://doi.org/10.1016/j.bioorg.2019.102932

31. Aggarwal, R.; Kumar, S.; Singh, S. P. J. Sulfur Chem. 2012, 33, 521-525. https://doi.org/10.1080/17415993.2012.711331

32. Kumar, S.; Aggarwal, R.; Kumar, V.; Sadana, R.; Patel, B.; Kaushik, P.; Kaushik, D. Eur. J. Med. Chem. 2016, 123, 718-726.

https://doi.org/10.1016/i.ejmech.2016.07.033

33. Elvidge, J. A.; Pickett, J. A. J. Chem. Soc. Perkin Trans 1. 1972, 12, 1483-1488.

34. https://doi.org/10.1039/p19720001483 